Article abstract-With a new method we measured the saturated very long chain fatty acids in the plasma of adrenoleukodystrophy (ALD) hemizygotes, ALD heterozygotes, and controls. ALD hemizygotes showed increased levels of hexacosanoate (C26 fatty acid) which represented $0.081 \pm 0.0066 \%$ (SEM) of total fatty acids, compared to $0.015 \pm 0.0032 \%$ in the controls. C25, C24, and C23 fatty acids were also increased, but the C22 and C20 fatty acids were normal. C26 levels were also increased in most ALD heterozygotes, with a mean level $0.057 \pm 0.0063 \%$ of total fatty acids. The technique can be used for diagnosis and carrier identification, and in the evaluation of therapy.

\title{
Adrenoleukodystrophy: Increased plasma content of saturated very long chain fatty acids
}

\author{
Hugo W. Moser, M.D., Ann B. Moser, A.B., Karen K. Frayer, A.B., Winston Chen, Ph.D.,
} Joseph D. Schulman, M.D., Brian P. O'Neill, M.D., and Yasuo Kishimoto, Ph.D.

Adrenoleukodystrophy (ALD) is an X-linked disorder characterized by demyelination of cerebral white matter and diminished adrenal response to ACTH. ${ }^{1}$ Adrenomyeloneuropathy (AMN) is a more chronic form of the disease which affects men in the second decade or later, and which involves the spinal cord. ${ }^{2}$ A neonatal form has been described ${ }^{3,4}$ and some female carriers are symptomatic. ${ }^{5}$ In postmortem tissues there is an accumulation of saturated or monounsaturated very long chain fatty acids in the cholesterol ester fractions of adrenal cortex and cerebral white matter.$^{6-7}$ The accumulated fatty acids are unbranched, with carbon chain length between 23 and 32 , but most contain 25 or 26 carbons. Less striking, but significant, excesses of these same fatty acids have also been reported in cultured muscle $e^{9,10}$ or fibroblasts. ${ }^{11,12}$ We now report that levels of these same fatty acids are increased in the plasma of patients and carriers. ${ }^{13}$

Methods and materials. The diagnosis of ALD was based on clinical history, neurologic examination, computed tomography (CT) scan, tests of adrenal functions, and a $\mathrm{C} 26: \mathrm{C} 22$ fatty acid ratio in cultured skin fibroblasts of 0.4 or higher. ${ }^{11,12}$ Obligate heterozygotes were mothers of patients with ALD or AMN, who also had at least one other affected relative. Others were designated by clonal analysis if clones of cultured skin fibroblasts demonstrated two types of cells: one with a normal fatty acid pattern, the other with a pattern characteristic of ALD hemizygotes. ${ }^{12,14}$ Dr. Barbara Migeon kindly provided the fibroblast clones.

In addition to the ALD-AMN hemizygotes and obligate heterozygotes, we studied two control groups: 22 persons 12 to 55 years old with no known disease, and 28 persons with different neurologic or metabolic diseases.

Samples ( 5 to $10 \mathrm{ml}$ ) of venous blood were added to heparinized test tubes. Plasma was separated within 2 hours and then frozen at $-10^{\circ} \mathrm{C}$. Most samples were obtained before breakfast. Some plasma samples were obtained in other parts of the United States or Europe, and mailed from a distance in containers filled with dry ice.

Fatty acid methyl esters were prepared as described elsewhere. ${ }^{11,12}$

From the John F. Kennedy Institute (Drs. Moser, Chen, and Kishimoto, Ms. Moser, and Ms. Frayer), the Departments of Neurology and Pediatrics, Johns Hopkins University (Dr. Moser), the National Institutes of Health, Child Health and Human Development (Dr. Schulman), and the Department of Neurology, Mayo Clinic and Foundation (Dr. O'Neill), Rochester, MN.

Supported in part by Grants HD 10981 and NS 10885 and 13513 from the Public Health Service and by Grant 6-271 from the National FoundationMarch of Dimes.

Accepted for publication February 11, 1981

Address correspondence and reprint requests to Dr. Moser, John F. Kennedy Institute, 707 N. Broadway, Baltimore, MD 21205. 


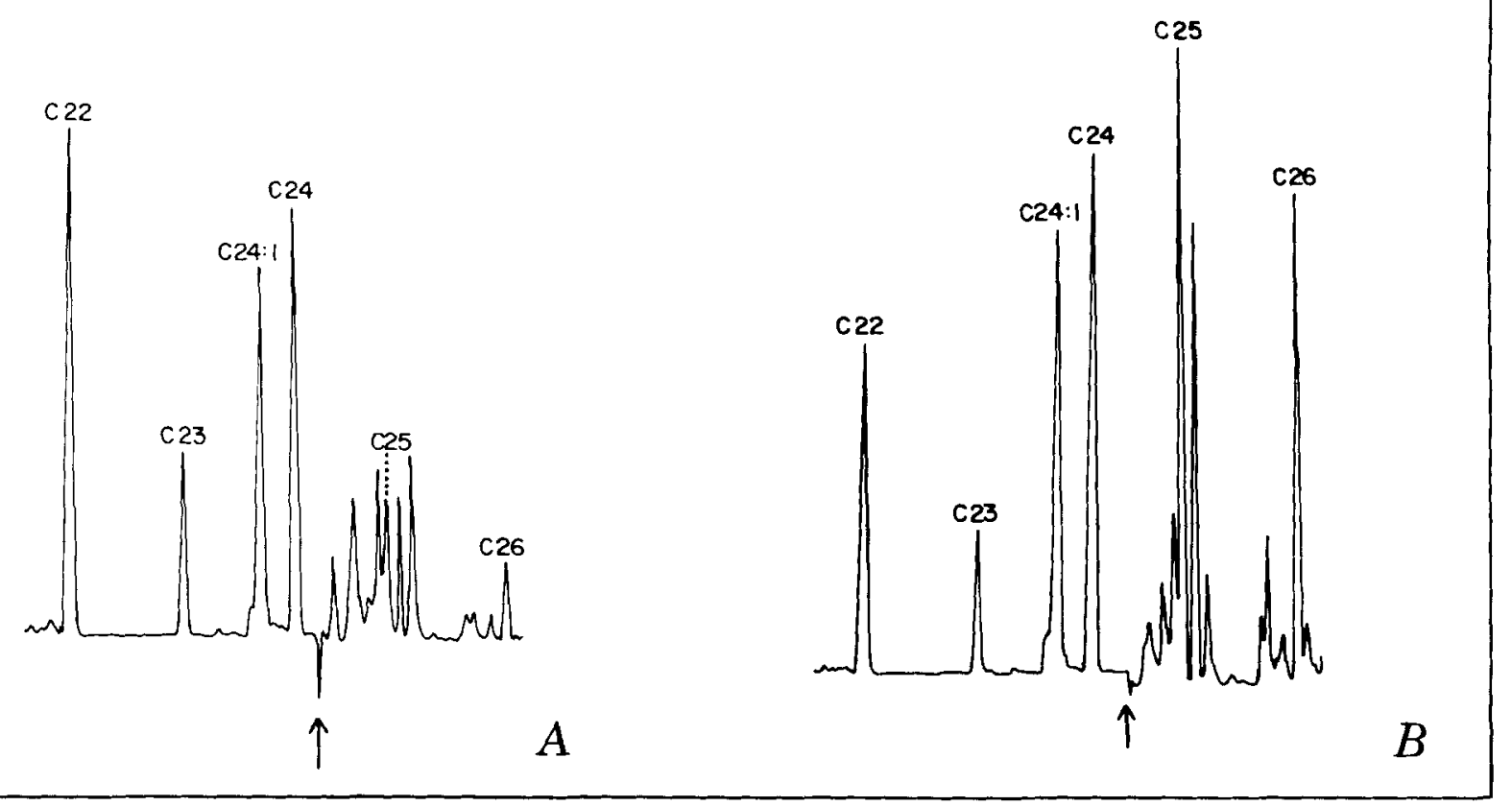

Figure 1. Saturated very long chain fatty acids in the plasma (A) of a 16-year-old normal male; (B) of a 12 -yearold patient with adrenoleukodystrophy. The gas-liquid chromatography method and retention times are described in the text. At the time indicated by the arrow, the sensitivity of the recording system was increased 16-fold, thus increasing the size of the peaks for the C25 and C26 fatty acids by that factor. The identity of the unlabeled peaks has not been established. Note that the C25 and C26 peaks are much higher in the ALD sample, and that in the ALD sample the C24 peak is larger than C22, while the reverse is true for the control sample. While in this tracing the C24:1 peak in the ALD sample is higher than in the control, this was not true for the other ALD patients (see text).

The purified fatty acid methyl esters were dissolved in $100 \mu \mathrm{l}$ of hexane, and $2.0 \mu \mathrm{l}$ was injected into a Hewlett Packard 5880A splitless injection port onto a 12-meter SP-2100 fused Silica Gel capillary column with an inside diameter of $0.2 \mathrm{~mm}$. Injection port temperature was $250^{\circ} \mathrm{C}$; detector temperature was $300^{\circ} \mathrm{C}$. The oven initial temperature was $150^{\circ} \mathrm{C}$. After 2 minutes it was raised to $285^{\circ} \mathrm{C}$ at $10^{\circ}$ per minute and maintained there for 5 minutes. Peaks were identified by co-chromatography with authentic standards in at least three systems (figure 1); the C26 fatty acid was also identified by combined mass spectrometry (Dr. Catherine Fenselau). Retention times for $\mathrm{C} 20, \mathrm{C} 22, \mathrm{C} 23, \mathrm{C} 24, \mathrm{C} 25$, and C26 fatty acids were $8.89,9.62,10.38,11.17,11.75$, and 12.54 minutes, respectively, and were constant to within \pm 0.02 minutes. The peaks were measured with a Hewlett-Packard $5880 \mathrm{~A}$ Level 4 integrator and expressed as percentage of total fatty acids with chain length of 14 carbons or more. Standard deviations of the differences between duplicate determinations were 11 to $13 \%$.

To measure the very long chain fatty acid content in the major lipid fractions, an aliquot of the washed total lipid extract was taken to dryness under nitrogen and subjected to alkaline methanolysis by adding $1 \mathrm{ml} 0.21 \mathrm{~N}$ methanolic $\mathrm{NaOH}$ and $2 \mathrm{ml}$ chloroform for 1 hour at room temperature. This treatment released fatty acids from triglycerides and glycerophospholipids. Cholesterol esters were partially split, while sphingolipids remained intact. The extract was then subjected to Folch partition; ${ }^{15}$ lipids in the washed lower phase were applied to a $3.0 \times 0.5 \mathrm{~cm}$ Unisil column, and eluted with $7 \mathrm{ml}$ each of hexane/benzene $6: 4$, chloroform, acetone/methanol $9: 1$, and methanol. The first fraction contained fatty acid methyl esters and unhydrolyzed cholesterol esters. The acetone/methanol fraction contained mainly glycolipids, and the methanol fraction mainly sphingomyelin. Cholesterol ester, glycolipid and sphingomyelin fractions were hydrolyzed with $1.5 \mathrm{ml} 1 \mathrm{~N}$ methanolic $\mathrm{HCl}$ at $75^{\circ} \mathrm{C}$ overnight. The cholesterol ester fraction was dissolved in $50 \mu \mathrm{l}$ benzene before methanolysis. The methyl esters were analyzed by gas-liquid chromatography as described above.

Results. Diurnal variation of plasma levels of very long chain fatty acids. Diurnal variation of very long chain fatty acids was studied in two normal persons, two patients with ALD, and one patient with AMN (figure 2). The values for the two ALD patients were the averages for two 3-day periods. The other studies were made on a single day. All 


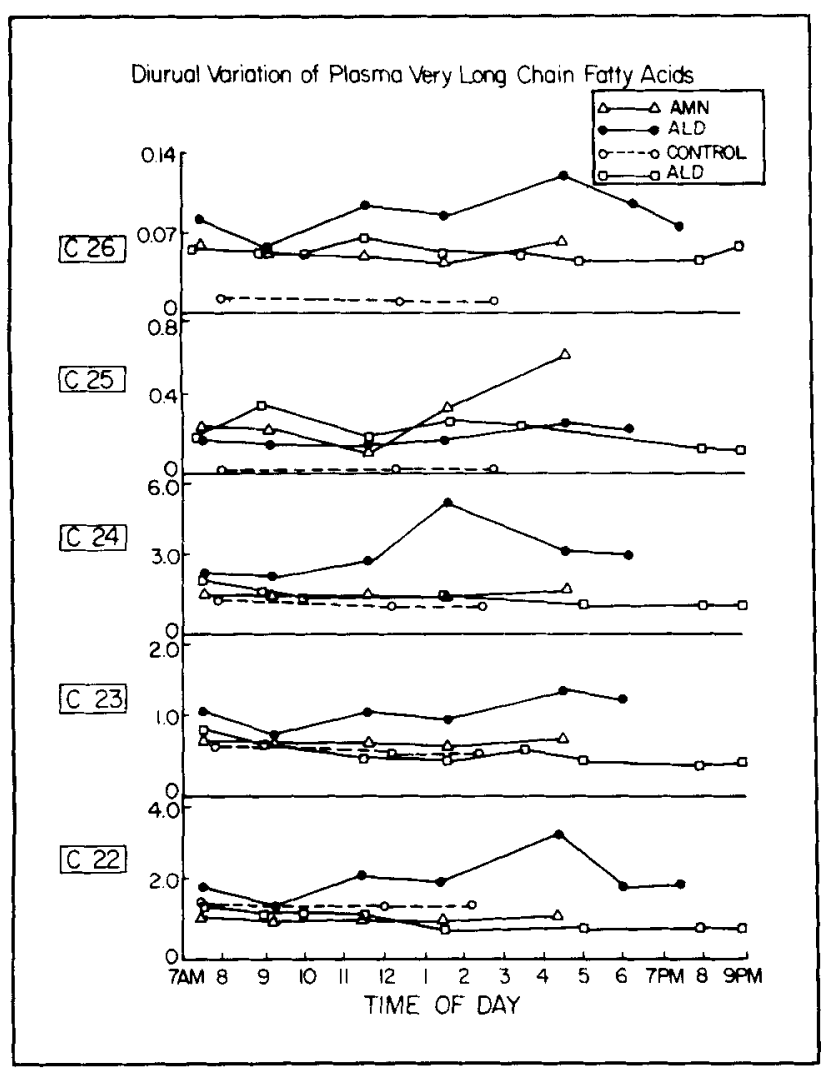

Figure 2. For each of the two ALD patients the diurnal variation studies were carried out for 3 days, and the points shown for these patients here represent the average of three values for each time period. We also performed a study in one additional normal person; this study gave results similar to those shown for the normal person included in the graph.

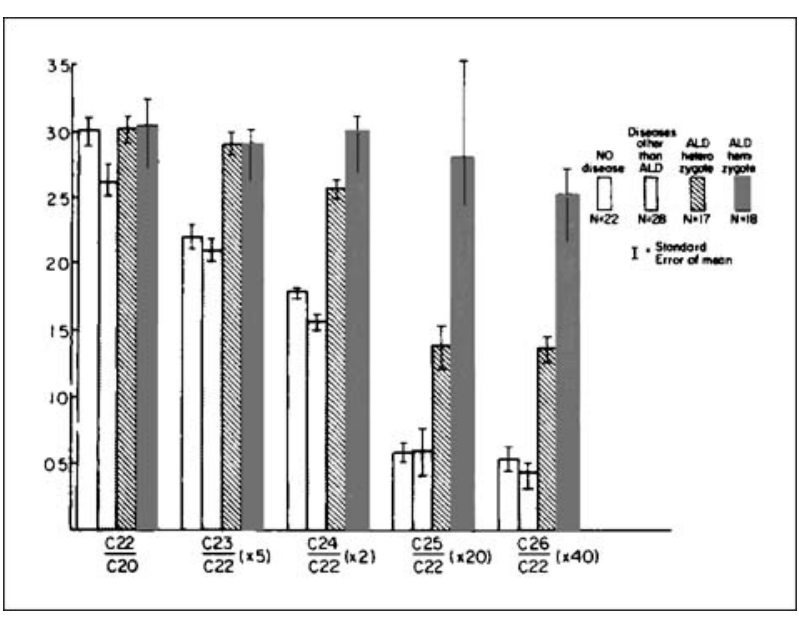

Figure 3. Ratios of plasma very long chain fatty acids in adrenoleukodystrophy.

the patients received diets that contained 20 to 45 $\mathrm{mg}$ of C26 fatty acid. Neither of the normal controls showed significant changes during the day, but the AMN patient showed an increase of $\mathrm{C} 25$ in the afternoon, other fatty acids remaining constant. Afternoon increases in C26, C24, and C22 fatty acids were observed in one ALD patient, but not in the others. The variations did not show a consistent pattern, and the range of variation was limited. Differences between ALD and controls were evident in both fasting and postprandial samples.

Total plasma levels of saturated very long chain fatty acids. The ALD hemizygotes and heterozygotes had significantly increased plasma levels of C24 and C26 fatty acids $(p<0.001)$, (table $1, \mathrm{~A}$ $D)$. The levels of C25 fatty acid were also increased, but statistical significance was not clear. For the ALD hemizygote, the increase was significant at the 0.01 level, but for the heterozygote the level of significance was between 0.01 and 0.05 . C25 levels varied in the ALD groups: In case 16 , table $1 \mathrm{D}$ and case 10 , table $1 \mathrm{C}$ they were more than 20 times normal.

The $\mathrm{C} 22: \mathrm{C} 20$ ratios showed no significant differences; ie, C22 fatty acid levels were not altered in comparison to $\mathrm{C} 20$. In contrast, the means of the C23:C22, C24:C22, C25:C22, and C26:C22 ratios were abnormally high in the ALD hemizygotes and heterozygotes. Differences between control groups and ALD groups gave $p$ values less than 0.001 for all of these ratios.

The degree of abnormality of these ratios increased with the fatty acid chain length: The C26:C22 and the C25:C22 ratios in ALD hemizygotes were 4.5 to 5 times control; for the C24:C22 ratio the difference was twofold, and the C23:C22 ratio difference was 50\%. For the ALD heterozygote, the increase in the $\mathrm{C} 25: \mathrm{C} 22$ and the $\mathrm{C} 26$ :C22 ratios was about half of that in the hemizygote. The difference between the $\mathrm{C} 26: \mathrm{C} 22$ ratios for ALD heterozygotes and hemizygotes gave $p$ values of less than 0.001 , but that between the C25:C22 ratios was not significant.

The results for the patients with diseases other than ALD or AMN did not differ from normal.

Not shown in the tables were values of C24:1 (nervonic acid). The mean plasma levels for this fatty acid, expressed as percentage of total fatty acids, were $0.679 \pm 0.062(\mathrm{SEM})$ for normals, $0.796 \pm 0.082$ for the ALD hemizygote, and 0.507 \pm 0.110 for the ALD heterozygote. These differences were not statistically significant. The mean level for the patients with other neurologic or metabolic disease was $1.004 \pm 0.087$, significantly higher $(p<0.01)$ than the means in the normals or ALD heterozygotes.

Some ALD patients and heterozygotes also showed peaks corresponding to C28, C30, or C32 fatty acids. These peaks were small and were not quantitated.

Although there were significant differences between mean values, some individual results over- 
Table 1(A). Plasma saturated very long chain fatty acids in persons without neurologic or metabolic diseases

\begin{tabular}{|c|c|c|c|c|c|c|c|c|c|c|c|}
\hline \multirow[b]{2}{*}{ Case } & \multirow{2}{*}{\multicolumn{2}{|c|}{ Sex/Age }} & & \multicolumn{8}{|c|}{ Expressed as $\%$ of total fatty acids } \\
\hline & & & & C20 & $\mathrm{C} 22$ & $\mathbf{C 2 3}$ & $\mathrm{C24}$ & $\overline{C 25}$ & $\mathrm{C26}$ & $\mathrm{C24/22}$ & $\overline{\mathrm{C} 26 / \mathrm{C} 22}$ \\
\hline 1 & M & 12 & & .795 & 3.21 & 1.93 & 2.65 & .071 & .044 & .826 & .014 \\
\hline 2 & & 12 & & .458 & 1.62 & .882 & 1.46 & .064 & .011 & .901 & .007 \\
\hline 3 & $\mathrm{~F}$ & 14 & & & 1.14 & .285 & .877 & .022 & .015 & .769 & .013 \\
\hline 4 & $\mathrm{M}$ & 15 & & & .868 & .334 & .706 & .019 & .011 & .813 & .013 \\
\hline 5 & $\mathrm{~F}$ & 15 & & & 2.52 & 1.13 & 1.92 & .111 & .014 & .762 & .006 \\
\hline 6 & $\mathrm{~F}$ & 16 & & & .985 & .361 & .778 & .024 & .012 & .790 & .012 \\
\hline 7 & M & 16 & & .409 & 1.58 & .458 & 1.25 & .128 & .008 & .791 & .005 \\
\hline 8 & M & 18 & & & .677 & .265 & .593 & .022 & .020 & .875 & .030 \\
\hline 9 & $\mathrm{~F}$ & 24 & & .453 & 1.39 & .552 & 1.18 & .025 & .012 & .849 & .009 \\
\hline 10 & $\mathrm{~F}$ & 27 & & .433 & 1.17 & .524 & .903 & .026 & .008 & .772 & .007 \\
\hline 11 & $\mathrm{M}$ & 29 & & .330 & .833 & .335 & .774 & 0 & .040 & .929 & .048 \\
\hline 12 & $\mathrm{M}$ & 30 & & .330 & .750 & & .780 & .014 & .016 & 1.04 & .021 \\
\hline 13 & $M$ & 32 & & .416 & 1.00 & .438 & .765 & .031 & .011 & .765 & .011 \\
\hline 14 & $\mathrm{M}$ & 35 & & .295 & .690 & .269 & .687 & .041 & .024 & .996 & .035 \\
\hline 15 & $M$ & 35 & & & .535 & .250 & .484 & .021 & .004 & .905 & .007 \\
\hline 16 & $\mathrm{~F}$ & 40 & & .350 & 1.03 & .563 & .944 & .033 & .014 & .917 & .041 \\
\hline 17 & $M$ & 40 & & .315 & 1.10 & .440 & .883 & .018 & .007 & .803 & .006 \\
\hline 18 & $\mathrm{M}$ & 42 & & .321 & 1.02 & .529 & .852 & .027 & .013 & .835 & .013 \\
\hline 19 & $\mathrm{M}$ & 45 & & .272 & .766 & .388 & .699 & .020 & .008 & .913 & .010 \\
\hline 20 & $\mathrm{~F}$ & 45 & & .381 & 1.09 & .524 & .821 & .024 & .008 & .753 & .007 \\
\hline 21 & $\mathrm{~F}$ & 54 & & .377 & 1.18 & .543 & .841 & .019 & .005 & .713 & .004 \\
\hline 22 & $\mathrm{~F}$ & 66 & & .340 & .910 & .423 & .682 & .028 & .008 & .749 & .009 \\
\hline Mean & & & & .392 & 1.18 & .543 & .979 & .036 & .0142 & .839 & .014 \\
\hline \pm SEM & & & & .026 & 0.13 & .081 & .104 & .007 & .0022 & .0182 & .0023 \\
\hline
\end{tabular}

lapped. For example, for case 16, table 1B the C26 fatty acid level and the C26:C22 fatty acid ratios were in the range of ALD hemizygotes and heterozygotes, respectively. However, the $\mathrm{C} 24$ level and the $\mathrm{C} 24: \mathrm{C} 22$ and the $\mathrm{C} 25: \mathrm{C} 22$ ratios were normal. None of the 50 controls showed abnormalities in all of the six criteria (C24, C25, and C26 levels, and the C26:C22, C25:C22, and C24:C22 ratios). The $\mathrm{C} 24: \mathrm{C} 22$ ratio was particularly consistent. The value was 1.0 or more in 32 of $34 \mathrm{ALD}$ hemizygotes or heterozygotes, and less than 1.0 in 49 of the 50 controls. The one control case (case 12 , table $1 \mathrm{~A}$ ) with a high $\mathrm{C} 24$ :C22 ratio had normal values in all other respects.

Distribution of very long chain fatty acids in different lipid classes. Both controls and ALD cases showed the highest percentage of very long chain fatty acids in the glycolipid and in the sphingomyelin fractions, and the C24 and C26 levels in both fractions were significantly increased in the ALD samples. ALD patients also showed increased very long chain fatty acid levels in the "alkaline methanolized fraction," which includes mainly glycerophosphatides and triglycerides. The ALD plasma cholesterol ester fractions did not show an increased percentage of very long chain fatty acids.

Comparison of changes in ALD plasma and cul- tured skin fibroblasts. We have studied the fatty acids of both cultured skin fibroblasts and plasma in 56 persons (figure 4). The $\mathrm{C} 26: \mathrm{C} 22$ ratio in plasma was about one-tenth of that in fibroblasts, and the alterations in controls, ALD heterozygotes, and ALD hemizygotes were similar. All 14 ALD hemizygotes had ratios more than two standard deviations above the control mean in both tissues and all 26 controls showed normal ratios. The 16 heterozygotes showed more variability. Three heterozygotes had normal plasma C26:C22 ratios, and four had normal ratios in skin fibroblasts. Nine heterozygotes had increased ratios in both samples. Heterozygotes with normal plasma ratios had increased ratios in the fibroblasts or vice versa.

Discussion. Plasma levels of very long chain fatty acids. We found a statistically significant increase in plasma levels of saturated very long chain fatty acids in patients with ALD or AMN and in carriers. The abnormality was most striking for the C25 and C26 and less so for the C24 and C23 fatty acids.

The absolute plasma levels of the very long chain fatty acids were low: In ALD patients they made up $0.08 \%$ of total fatty acids compared to $0.014 \%$ in controls. These low levels probably ac- 
Table 1(B). Plasma saturated very long chain fatty acids in patients with disorders other than adrenoleukodystrophy

\begin{tabular}{|c|c|c|c|c|c|c|c|c|c|c|c|}
\hline \multirow{3}{*}{$\begin{array}{c}\text { Case } \\
1\end{array}$} & & & & \multicolumn{8}{|c|}{ Expressed as \% of total fatty acids } \\
\hline & \multicolumn{2}{|c|}{ Sex/Age } & Diagnosis & $\mathrm{C20}$ & $\mathrm{C22}$ & C23 & $\mathrm{C} 24$ & $\mathrm{C25}$ & C26 & $\mathrm{C24/22}$ & $\mathrm{C} 26 / 22$ \\
\hline & $\mathbf{M}$ & 22 & Adrenal & .642 & 1.32 & .505 & .801 & .060 & .008 & .607 & .006 \\
\hline 2 & M & 35 & \multirow{2}{*}{$\begin{array}{l}\text { Multiple } \\
\text { sclerosis }\end{array}$} & .346 & .801 & .306 & .597 & .019 & .007 & .745 & .009 \\
\hline 3 & $\mathbf{F}$ & 32 & & .757 & 2.13 & .621 & 1.60 & .036 & .048 & .751 & .023 \\
\hline 4 & M & & " " & .644 & 2.22 & .811 & 2.00 & .052 & .033 & .901 & .015 \\
\hline 5 & M & 49 & $"$ & .538 & 1.42 & .615 & .733 & .024 & 0 & .516 & 0 \\
\hline 6 & M & 54 & " " " & .503 & 1.36 & .572 & 1.10 & .044 & .023 & .809 & .017 \\
\hline 7 & $\mathrm{M}$ & 6 & $\begin{array}{l}\text { Pelizaeus- } \\
\text { Merzbacher } \\
\text { disease }\end{array}$ & & 2.06 & .909 & 1.62 & .052 & .015 & .786 & .007 \\
\hline 8 & M & 11 & " " & .463 & 1.08 & .446 & .602 & .015 & 0 & .557 & 0 \\
\hline 9 & M & 13 & $" \quad "$ & .439 & .982 & .384 & .760 & .020 & .010 & .774 & .010 \\
\hline 10 & $\mathrm{M}$ & $11 / 2$ & $\begin{array}{l}\text { Metachromatic } \\
\text { leukodystrophy }\end{array}$ & .479 & 1.15 & .554 & .913 & & .015 & .794 & .013 \\
\hline 11 & $\mathrm{~F}$ & 5 & " $"$ & .552 & .979 & .347 & .741 & .041 & .010 & .757 & .010 \\
\hline 12 & $\mathrm{~F}$ & 9 & " " " & .666 & 1.95 & .542 & 1.45 & .114 & .033 & .743 & .017 \\
\hline 13 & $\mathrm{~F}$ & 3 & $\begin{array}{l}\text { Leukodystrophy, } \\
\text { type unknown }\end{array}$ & 1.23 & 2.84 & 1.13 & 1.85 & 0 & .018 & .651 & .006 \\
\hline 14 & $\mathrm{~F}$ & 5 & " " " & .784 & 1.67 & .606 & .948 & 0 & .036 & .568 & .022 \\
\hline 15 & M & 30 & $\begin{array}{l}\text { Fabry } \\
\text { disease }\end{array}$ & .343 & .621 & .287 & .589 & .024 & .011 & .949 & .018 \\
\hline 16 & M & 48 & $\begin{array}{l}\text { Spastic } \\
\text { paraparesis }\end{array}$ & .311 & .764 & .312 & .687 & .022 & .012 & .899 & .016 \\
\hline 17 & $\mathrm{~F}$ & 48 & $\begin{array}{c}\text { Spinocerebellar } \\
\text { degeneration }\end{array}$ & .289 & .785 & .300 & .554 & .172 & .010 & .706 & .013 \\
\hline 18 & $\mathbf{M}$ & 38 & " " & .245 & .632 & .214 & .600 & .015 & .010 & .949 & .016 \\
\hline 19 & $\mathrm{~F}$ & 17 & $" \quad "$ & .613 & 1.84 & .748 & 1.49 & .034 & .069 & .810 & .038 \\
\hline 20 & $\mathrm{~F}$ & 11 & $\begin{array}{l}\text { Charcot-Marie } \\
\text { Tooth disease }\end{array}$ & .378 & 1.05 & .442 & .842 & .020 & .010 & .802 & .010 \\
\hline 21 & M & & $\begin{array}{l}\text { Peripheral } \\
\text { neuropathy }\end{array}$ & .511 & 1.38 & .660 & 1.19 & .036 & .005 & .862 & .004 \\
\hline 22 & $\mathrm{~F}$ & & " " " & .292 & 1.02 & .352 & .885 & .020 & .006 & .868 & .006 \\
\hline 23 & $\mathrm{~F}$ & 14 & $"$ & & 1.12 & .444 & .809 & .032 & .009 & .722 & .008 \\
\hline 24 & $\mathrm{~F}$ & & $"$ & .460 & 1.19 & .568 & 1.01 & .007 & .006 & .849 & .005 \\
\hline 25 & $\mathbf{M}$ & 50 & " " & .361 & 1.09 & .530 & .733 & .024 & 0 & .672 & 0 \\
\hline 26 & $\mathrm{~F}$ & 3 & $\begin{array}{l}\text { Psychomotor } \\
\text { retardation }\end{array}$ & & .812 & .523 & .617 & .029 & .017 & .760 & .021 \\
\hline 27 & $\mathrm{~F}$ & $21 / 2$ & $\begin{array}{l}\text { Myoclonus } \\
\text { epilepsy }\end{array}$ & .626 & 1.39 & .739 & 1.29 & .040 & .013 & .928 & .009 \\
\hline 28 & $\mathrm{~F}$ & 5 & $\begin{array}{l}\text { Cornelia deLange } \\
\text { syndrome }\end{array}$ & .564 & 1.49 & .685 & 1.24 & .022 & .010 & .780 & .006 \\
\hline Mean & & & & .521 & 1.33 & .541 & 1.01 & .036 & .016 & .768 & .012 \\
\hline \multicolumn{4}{|l|}{ SEM } & .042 & .102 & .089 & .077 & .0075 & .0028 & .022 & .0016 \\
\hline $\begin{array}{l}\text { The d } \\
\text { patho } \\
\text { destr }\end{array}$ & 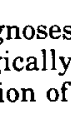 & $\begin{array}{l}\text { of } P \\
\text { The } \\
\text { whit }\end{array}$ & $\begin{array}{l}\text { eus-Merzbacher dis } \\
\text { ients with leukodys } \\
\text { atter on CT scan. }\end{array}$ & se wer & lade 0 & e bas & $\begin{array}{l}\text { clinic } \\
\text { with } \\
\text { d out }\end{array}$ & $\begin{array}{l}\text { criteria } \\
\text { arly pr } \\
\text { enzyme }\end{array}$ & $\begin{array}{l}\mathrm{d} \text { have } \\
\text { essive } \\
\text { says. }\end{array}$ & $\begin{array}{l}\text { ot been } \\
\text { ability }\end{array}$ & $\begin{array}{l}\text { onfirmed } \\
\text { nd severe }\end{array}$ \\
\hline
\end{tabular}

count for the fact that the abnormalities were not described earlier. The capillary gas-liquid chromatography technique (as opposed to the more commonly used packed column technique) is valuable since it gives clearly separated peaks and reproducible retention times. The conditions used are not suitable for the separation of shorter chain or unsaturated fatty acids, and the very long chain alpha hydroxy fatty acids are excluded in the thinlayer chromatography separation of fatty acid methyl esters.

Use of plasma assay for diagnosis. A technique 
Table 1(C). Plasma saturated very long chain fatty acids in women who are obligate heterozygotes for adrenoleukodystrophy

\begin{tabular}{|c|c|c|c|c|c|c|c|c|c|}
\hline \multirow[b]{2}{*}{ Case } & \multirow[b]{2}{*}{ Age } & \multicolumn{8}{|c|}{ Expressed as $\%$ of total fatty acids } \\
\hline & & $\mathrm{C20}$ & $\mathrm{C} 22$ & $\overline{\mathrm{C23}}$ & $\mathrm{C24}$ & $\mathbf{C 2 5}$ & C26 & $\mathrm{C} 24 / \mathrm{C} 22$ & $\mathrm{C26} / 22$ \\
\hline 1 & 6 & .556 & 1.50 & .930 & 1,89 & .109 & .075 & 1.26 & .050 \\
\hline 2 & 8 & & 1.72 & 1.074 & 2.27 & .104 & .049 & 1.32 & .028 \\
\hline 3 & 8 & .932 & 2.12 & 1.48 & 3.15 & .198 & .099 & 1.49 & .047 \\
\hline 4 & 9 & .424 & 1.15 & .722 & 1.48 & .075 & .037 & 1.29 & .032 \\
\hline 5 & 23 & & 1.43 & .804 & 1.51 & .083 & .032 & 1.06 & .022 \\
\hline 6 & 30 & .801 & 2.14 & 1.24 & 2.68 & .138 & .100 & 1.25 & .047 \\
\hline 7 & 31 & .237 & .614 & .317 & .685 & .028 & .017 & 1.12 & .028 \\
\hline 8 & 31 & 1.07 & 3.04 & 1.87 & 3.95 & .213 & .105 & 1.30 & .035 \\
\hline 9 & 33 & .395 & 1.09 & .652 & 1.72 & .084 & .057 & 1.58 & .052 \\
\hline 10 & 35 & .581 & 2.21 & 1.07 & 2.48 & 1.43 & .058 & 1.12 & .026 \\
\hline 11 & 35 & .386 & 1.17 & .634 & 1.58 & .013 & .049 & 1.35 & .042 \\
\hline 12 & 38 & .619 & 2.02 & 1.12 & 2.87 & .170 & .073 & 1.42 & .036 \\
\hline 13 & 45 & .527 & 1.57 & .663 & 1.47 & .279 & .029 & 0.94 & .018 \\
\hline 14 & 55 & .328 & 1.08 & .734 & 1.40 & .066 & .034 & 1.30 & .032 \\
\hline 15 & 59 & .495 & 1.58 & .832 & 1.72 & .099 & .034 & 1.09 & .022 \\
\hline 16 & 59 & .456 & 1.58 & .787 & 2.21 & .105 & .063 & 1.40 & .040 \\
\hline 17 & 65 & .623 & 1.51 & .542 & 2.95 & .136 & .059 & 1.95 & .039 \\
\hline Mean & & .562 & 1.63 & .967 & $2.07 * *$ & .196 & $.057^{* *}$ & $1.31^{* *}$ & $.035^{* * *}$ \\
\hline SEM & & .055 & 0.141 & .094 & 0.20 & .079 & .0063 & .056 & .0024 \\
\hline
\end{tabular}

that permits the diagnosis of ALD with less than $1 \mathrm{ml}$ of plasma is more useful than previous approaches, but there are limitations. The type, nature, and conditions of the gas-liquid chromatography procedure must be precisely specified. Conditions suitable for the more common fatty acids do not permit quantitation of very long chain fatty acids. The low absolute level requires care to exclude contaminants and to test reproducibility.

The mean of the plasma levels of very long chain fatty acids is abnormal in both ALD hemizygotes and heterozygotes. However, the mean level does not provide information about the degree of overlap, or the occurrence of false positives or of false negatives. Levels of $\mathrm{C} 26$ fatty acids were high in 5 of 50 controls: cases 1 and 11 in table $1 \mathrm{~A}$ and cases 3,14 , and 19 in table $1 \mathrm{~B}$. However, other results were normal in these subjects, and assessment of all measurements sets them apart from the ALD cases.

In the ALD hemizygotes, we did not encounter false negatives for $\mathrm{C} 26$ levels, and the combined use of all six criteria gave reliable identification. Two cases (cases 1 and 10, table 1D) were boys, aged 4 and 12, respectively, who were free of demonstrable adrenal or brain disease but were brothers of patients with proven ALD. The C26:C22 ratios in their cultured skin fibroblasts were ab- normal ( 0.812 and 0.700$)$, and we classified them as presymptomatic ALD. Our series is still small, and we may yet encounter false negatives or false positives. We therefore perform both the fibroblast and the plasma assays for diagnosis.

Some heterozygotes showed plasma elevations of very long chain fatty acids that were as marked as those in the hemizygotes, and which we also observed in cultured skin fibroblasts heterozygotes had normal or borderline plasma values (cases 5, 7, 13, and 14, table 1C). However, three of these cases had abnormal $\mathrm{C} 26: \mathrm{C} 22$ ratios in fibroblasts: $0.348,0.335$, and 0.336 for cases 5,7 , and 13 , respectively, compared to a normal ratio of $0.077 \pm 0.032$. Conversely, case 2 showed a borderline $\mathrm{C} 26: \mathrm{C} 22$ ratio in cultured skin fibroblasts $(0.160)$, while most of the parameters for the plasma very long chain fatty acids were $a b-$ normal. For the identification of the heterozygote it is therefore important to study both fibroblasts and plasma.

The metabolic defect in $A L D$. The basic metabolic defect in ALD is unknown. The original observation that the accumulation of very long chain fatty acids was most prominent in the cholesterol ester fraction ${ }^{6-8}$ led to the hypothesis that there was a defect in a specific cholesterol esterase. However, the activities of cholesterol esterases were normal ${ }^{16,17}$ and the very long chain fatty acid 
Table 1(D). Plasma saturated very long chain fatty acids in patients with adrenoleukodystrophy or adrenomyeloneuropathy

\begin{tabular}{|c|c|c|c|c|c|c|c|c|c|c|}
\hline \multirow{2}{*}{\multicolumn{2}{|c|}{ Case/Age }} & \multicolumn{8}{|c|}{ Expressed as \% of total fatty acids } & \multirow[b]{2}{*}{ Comments } \\
\hline & & $\mathrm{C} 20$ & C22 & $\mathrm{C23}$ & $\mathrm{C24}$ & $\mathrm{C25}$ & C26 & $\mathrm{C} 24 / 22$ & C26/22 & \\
\hline 1 & 4 & & .916 & .548 & 1.41 & .047 & .038 & 1.54 & .041 & Asymptomatic; 8 yr. old; \\
\hline 2 & 5 & .357 & 1.053 & .519 & 1.85 & .101 & .067 & 1.76 & .064 & 2 wks before death \\
\hline 3 & 6 & & 1.31 & .55 & 1.11 & .038 & .130 & 0.85 & .099 & Typical ALD \\
\hline 4 & 6 & & 1.12 & .688 & 1.92 & .182 & .080 & 1.71 & .071 & ALD, decorticate state \\
\hline 5 & 7 & .32 & 1.09 & .64 & 1.52 & .081 & .069 & 1.39 & .063 & ALD, very severe disability \\
\hline 6 & 7 & .943 & 1.17 & .635 & 1.43 & .123 & .098 & 1.22 & .084 & ALD, very severe disability \\
\hline 7 & 8 & & 1.54 & 1.14 & 2.42 & .213 & .083 & 1.57 & .054 & $\begin{array}{l}\text { ALD, very severe } \\
\text { disability }\end{array}$ \\
\hline 8 & 8 & .358 & 1.25 & .918 & 1.84 & .094 & .051 & 1.47 & .041 & $\begin{array}{l}\text { Adrenal insufficiency, } \\
\text { neurologically normal }\end{array}$ \\
\hline 9 & 9 & .31 & 1.20 & .598 & 1.95 & .060 & .089 & 1.63 & .074 & $\begin{array}{l}\text { ALD, very severe } \\
\text { disability }\end{array}$ \\
\hline 10 & 12 & .334 & 1.28 & .885 & 2.26 & .162 & .067 & 1.77 & .052 & $\begin{array}{l}\text { Asymptomatic; brother of } \\
\text { case } 4\end{array}$ \\
\hline 11 & 12 & 827 & 1.75 & 1.00 & 3.12 & 197 & 143 & 1.78 & .082 & $\begin{array}{l}\text { ALD proven by brain } \\
\text { biopsy, decorticate state }\end{array}$ \\
\hline 12 & 12 & .530 & 1.83 & 1.03 & 2.79 & 182 & .087 & 1.52 & .048 & $\begin{array}{l}\text { ALD, very severe } \\
\text { disability }\end{array}$ \\
\hline 13 & 14 & .730 & 2.85 & 1.69 & 3.77 & .227 & .122 & 1.32 & .043 & $\begin{array}{l}\text { ALD, very severe } \\
\text { disability }\end{array}$ \\
\hline 14 & 16 & .703 & 2.17 & 1.10 & 3.00 & 139 & .094 & 1.38 & .043 & $\begin{array}{l}\text { ALD, very severe } \\
\text { disability }\end{array}$ \\
\hline 15 & 18 & .306 & .680 & .427 & 1.19 & .079 & .071 & 1.75 & 104 & ALD, severe disability \\
\hline & 18 & .340 & .710 & .360 & 1.25 & .100 & .055 & 1.76 & .077 & ALD, severe disability \\
\hline 17 & 29 & .361 & 1.09 & .596 & 1.41 & .738 & .065 & 1.29 & .060 & $\begin{array}{l}\text { AMN, severe spinal cord } \\
\text { involvement }\end{array}$ \\
\hline & 38 & & 1.005 & .675 & 1.54 & .309 & .055 & 1.53 & .055 & AMN, moderate disability \\
\hline $\mathrm{Me}$ & & .494 & 1.33 & .777 & $1.99 * *$ & $.171 *$ & $.081^{* *}$ & $1.52 * *$ & $.064^{* *}$ & \\
\hline $\mathrm{SE}$ & & .063 & 0.13 & .077 & .179 & .038 & .0066 & .058 & .0046 & \\
\hline \multicolumn{11}{|c|}{$\begin{array}{l}\text { The values shown for case } 5 \text { represent the mean of } 4 \text { determinations on separate plasma samples; the values for cases } \\
11,15 \text {, and } 17 \text { represent the means of } 16,4 \text {, and } 6 \text { determinations, respectively. A packed rather than a capillary gas- } \\
\text { liquid chromatography column was used for the analysis of the sample from case } 3 \text {. The values marked with a double } \\
\text { asterisk differ from control with a } p \text { value }<0.001 \text {. The value marked with a single asterisk differs from control with } \\
\text { a } p \text { value }<0.01 \text {. }\end{array}$} \\
\hline
\end{tabular}

excess is not confined to the cholesterol esters. It has also been demonstrated in gangliosides, ${ }^{6,18}$ sphingomyelins, ${ }^{11}$ and free fatty acids, ${ }^{8}$ suggesting that the defect involves metabolism of the very long chain fatty acids themselves. Their accumulation in the cholesterol ester fraction of the cerebral white matter and adrenal cortex could be secondary. Plasma low-density lipoproteins are precursors of adrenal cholesterol, ${ }^{19}$ and free fatty acids seem to be the precursors of cholesterol ester fatty acids in both brain ${ }^{20}$ and adrenal gland. ${ }^{21}$

Our new observations provide further evidence for the hypothesis that the primary defect involves the metabolism of very long chain fatty acids, since the plasma cholesterol ester fraction was not abnormal, and the abnormal fatty acids were associated with a variety of other lipid classes (table
2). The nature of this presumed abnormality of fatty acid metabolism is unknown. We are evaluating a possible abnormality of a peroxisomal $\beta$ oxidation system. ${ }^{5}$ The fatty acid ratios (figure 3 ) suggest that the abnormality involves mainly C25 and $\mathrm{C} 26$ saturated fatty acids, with lesser involvement of C24 and C23 fatty acids, and no alteration of C22 or C20 fatty acid metabolism.

Exogenous or endogenous origin of very long chain fatty acids. It is of practical significance to determine whether the accumulated fatty acids are of exogenous or endogenous origin. If exogenous, it may be useful to restrict dietary very long chain fatty acids. C25 and C26 fatty acids are constituents of plant cutin, ${ }^{22}$ and the average daily American diet contains approximately 15 to 40 mg of C26 fatty acid (Moser AE and Moser HW, 
Table 2. Very long chain fatty acids in various plasma lipid fractions in patients with ALD or AMN and controls

\begin{tabular}{|c|c|c|c|c|c|}
\hline & \multicolumn{5}{|c|}{ Expressed as $\%$ of total fatty acids with standard deviations } \\
\hline & ALD-AMN & $(\mathbf{N})$ & Control & (N) & $p$ \\
\hline \multirow{3}{*}{$\begin{array}{l}\text { Alkaline } \\
\text { methanolyzed }\end{array}$} & $22: 00.122 \pm 0.175$ & (11) & $0.074 \pm 0.068$ & (6) & $>0.05$ \\
\hline & $24: 00.128 \pm 0.055$ & & $0.047 \pm 0.027$ & & $<0.001$ \\
\hline & $26: 00.068 \pm 0.069$ & & $0.011 \pm 0.007$ & & $<0.001$ \\
\hline \multirow[t]{3}{*}{ Sphinogmyelin } & $22: 021.9 \pm 2.93$ & (7) & $20.0 \pm 2.42$ & (4) & $>0.02$ \\
\hline & $24: 029.7 \pm 5.93$ & & $16.1 \pm 1.29$ & & $<0.001$ \\
\hline & $26: 00.43 \pm 0.17$ & & $.097 \pm 0.011$ & & $<0.001$ \\
\hline \multirow[t]{3}{*}{ Glycolipid } & $22: 09.84 \pm 2.56$ & (6) & $14.1 \pm 4.88$ & (5) & $>0.02$ \\
\hline & $24: 033.7 \pm 8.47$ & & $27.1 \pm 1.29$ & & \\
\hline & $26: 02.11 \pm 0.63$ & & $0.91 \pm 0.62$ & & $<0.001$ \\
\hline $\begin{array}{l}\text { Cholesterol } \\
\text { ester }\end{array}$ & $26: 00.22 \pm 0.14$ & (3) & $0.56 \pm 0.25$ & $(2)$ & $>0.1$ \\
\hline
\end{tabular}

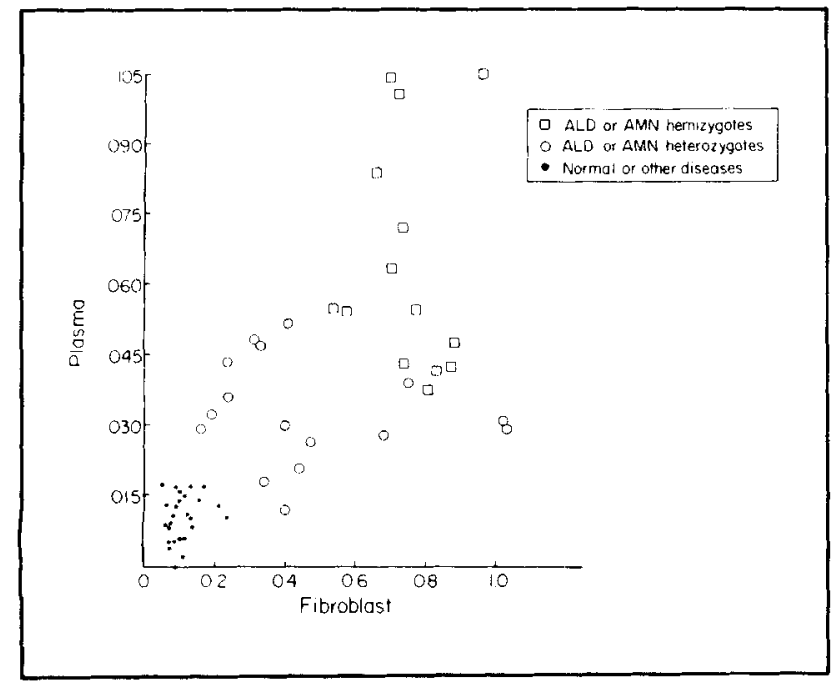

Figure 4. Relationship between C26:C22 fatty acid ratio in plasma and cultured skin fibroblasts.

unpublished observation). We showed that orally administered deuterated C26 fatty acid was incorporated into the brain cholesterol esters of one ALD patient. ${ }^{23}$ However, endogenous synthesis of very long chain fatty acids takes place in the nervous system, ${ }^{24}$ and it is not yet possible to assess the relative importance of exogenous and endogenous sources. The patterns of plasma changes also provide some leads. Excessive C26, C25, and C24 levels were noted in ALD heterozygotes and in hemizygotes, but not in patients with advanced neurologic disability from other causes, suggesting that the plasma abnormalities are not the consequence of myelin breakdown. Similarly, plasma C24:1 levels were not increased in ALD, although C24:1 fatty acid makes up $40 \%$ of the nonhydroxy fatty acids in myelin cerebrosides, compared to
$3.5 \%$ and $1 \%$ for $\mathrm{C} 25$ and $\mathrm{C} 26 .{ }^{25}$ If the elevated plasma very long chain fatty acids were derived from disintegrating myelin, there should be a greater excess of C24:1 than of C25 and C26, whereas the reverse was true. For these reasons we think it likely that most of the excess long chain fatty acids in ALD plasma are of dietary origin.

Implications for therapeutic trials. The possibility that the very long chain fatty acids accumulated in ALD are of dietary origin provides the rationale for a therapeutic trial of the effect of dietary restrictions, which we are now conducting. The observation that plasma very long chain fatty acid levels are elevated in ALD is of key importance to this therapeutic trial. Periodic measurements of plasma fatty acids may help determine whether the dietary restriction can reduce the "body burden" of very long chain fatty acids, may help assess the degree to which the patients have followed the diet, and provide additional insights about disease mechanism.

\section{Acknowledgments}

We thank Ms. Deborah Regney for expert technical assistance and Drs. John A. Barranger, Grosvenor W. Bissell, Benjamin R. Brooks, Enrique Chaves, Paul R. Dyken, I. Zachary Dyme, John Griffin, Fred J. Kader, Ira T. Lott, Barbara R. Migeon, Jerome V. Murphy, James M. Powers, Frank R. Schuster, David Sillence, Lawrence G. Tomasi, Hugh Walker, and Charles A. Williams for permission to study samples of patients under their care.

\section{References}

1. Schaumburg HH, Powers LM, Raine CS, et al. Adrenoleukodystrophy: a clinical and pathological study of 17 cases. Arch Neurol 1975;32:577-91.

2. Griffin JW, Goren E, Schaumburg $H$, et al. Adrenomye- 
loneuropathy: a probable variant of adrenoleukodystrophy. I. clinical and endocrinological aspects. Neurology (Minneap) $1977 ; 27: 1107-13$.

3. Ulrich J, Herschkowitz N, Heitz P, et al. Adrenoleukodystrophy: preliminary report of a connatal case: light- and electron microscopical, immunohistochemical, and biochemical findings. Acta Neuropathol 1978;43:77-83.

4. Manz HJ, Schuelein M, McCullough DC, et al. New phenotypic variant of adrenoleukodystrophy: pathologic, ultrastructural, and biochemical study in two brothers. J Neurol Sci 1980;45:245-60

5. Moser HW, Moser AB, Kawamura N, et al. Adrenoleukodystrophy: delineation of the phenotype and implications of recent genetic and biochemical studies. Johns Hopkins Med J 1980;147:217-24.

6. Igarashi M, Schaumburg HH, Powers J, et al. Fatty acid abnormality in adrenoleukodystrophy. J Neurochem 1976;26:851-60.

7. Menkes JH, Corbo LM. Adrenoleukodystrophy: accumulation of cholesterol esters with very long chain fatty acids. Neurology (Minneap) 1977;27:928-32.

8. Ramsey RB, Banik NL, Davison AN. Adrenoleukodystrophy: brain cholesterol esters and other neutral lipids. J Neurol Sci 1979;40:189-96.

9. Askanas V, McLaughlin J, Engel WK, et al. Abnormalities in cultured muscle and peripheral nerve of a patient with adrenomyeloneuropathy. N Engl J Med 1979;301:588-90.

10. McLaughlin J, Askanas V, Engel WK. Adrenomyeloneuropathy: increased accumulation of very long chain fatty acids in cultured skeletal muscle. Biochem Biophys Res Commun 1980;92:1202-7.

11. Kawamura N, Moser AB, Moser HW, et al. High concentration of hexacosanoate in cultured skin fibroblast from adrenoleukodystrophy patients. Biochem Biophys Res Commun 1978;82:114-20.

12. Moser HW, Moser AB, Kawamura N, et al. Adrenoleukodystrophy: elevated C26 fatty acid in cultured skin fibroblasts. Ann Neurol 1980;7:542-9.

13. Moser AB, Chen W, Kawamura N, et al. Above-normal plasma hexacosanoate levels in adrenoleukodystrophy and adrenomyeloneuropathy. Neurology (Ny) 1980;30:450.

14. Migeon BR, Moser HW, Moser AB, et al. Adrenoleuko- dystrophy: evidence for X-linkage, inactivation, and selection favoring mutant allele in heterozygous cells. Am J Hum Genet 1980;32:157 A.

15. Folch J, Lees M, Sloane-Stanley GH. A simple method for the isolation and purification of total lipids from animal tissues. J Biol Chem 1957;266:497-509.

16. Ogino T, Schaumburg HH, Suzuki K, Kishimoto Y, Moser AB. Metabolic studies of adrenoleukodystrophy. In: Palo $J$, ed. Myelination and demyelination. New York: Plenum Publishing Corp, 1978:601.

17. Michels VV, Beaudet AL. Cholesteryl lignocerate hydrolysis in adrenoleukodystrophy. Pediatr Res 1980;14:21-3.

18. Igarashi $\mathbf{M}$, Belchis $\mathrm{D}$, Suzuki $\mathrm{K}$, et al. Brain gangliosides in adrenoleukodystrophy. $J$ Neurochem 1976;27:327-8.

19. Kovanen PT, Faust JR, Brown MS, Goldstein JL. Low density lipoprotein receptors in bovine adrenal cortex: I. receptor mediated uptake of low density lipoprotein and utilization of its cholesterol for steroid synthesis in cultured adrenocortical cells. Endocrinology 1979;104:599-609.

20. Eto Y, Suzuki K. Cholesterol ester metabolism in the brain: properties and subcellular distribution of cholesterol-esterifying enzymes and cholesterol ester hydrolases in adult rat brain. Biochim Biophys Acta 1971;239:293-311.

21. Shyamala G, Lossow WJ, Chaikoff IL. Esterification of cholesterol by rat adrenal gland homogenates and subcellular components. Biochim Biophys Acta 1960;116:543-54.

22. Kolattukudy PE, Croteau R, Brown L. Structure and biosynthesis of cuticular lipids: hydroxylation of palmitic acid and decarboxylation of $\mathrm{C} 28, \mathrm{C} 30$, and C32 acids in Vicia faba flowers. Plant Physiol 1974;54:670-7.

23. Kishimoto Y, Moser HW, Kawamura N, Platt M, Pallante SL, Fenselau C. Adrenoleukodystrophy: evidence that abnormal very long chain fatty acids of brain cholesterol esters are of exogenous origin. Biochem Biophys Res Commun 1980;96:69-76.

24. Cassagne C, Darriet D. Biosynthesis of very long chain fatty acids by the sciatic nerve of the rabbit. FEBS Lett 1978;90:336-40.

25. O'Brien JS, Sampson EL. Fatty acid and fatty aldehyde composition of the major brain lipids in normal human gray matter, white matter, and myelin. J Lipid Res $1965 ; 6: 545-51$. 


\section{Neurology}

Adrenoleukodystrophy: Increased plasma content of saturated very long chain fatty acids Hugo W. Moser, Ann B. Moser, Karen K. Frayer, et al.

Neurology 1981;31;1241

DOI 10.1212/WNL.31.10.1241

This information is current as of October 1,1981

Updated Information \&

Services

Citations

Permissions \& Licensing

Reprints including high resolution figures, can be found at: http://n.neurology.org/content/31/10/1241.full

This article has been cited by 7 HighWire-hosted articles: http://n.neurology.org/content/31/10/1241.full\#\#otherarticles

Information about reproducing this article in parts (figures,tables) or in its entirety can be found online at:

http://www.neurology.org/about/about_the_journal\#permissions

Information about ordering reprints can be found online:

http://n.neurology.org/subscribers/advertise

Neurology $®$ is the official journal of the American Academy of Neurology. Published continuously since 1951, it is now a weekly with 48 issues per year. Copyright (C) 1981 by the American Academy of Neurology. All rights reserved. Print ISSN: 0028-3878. Online ISSN: 1526-632X.

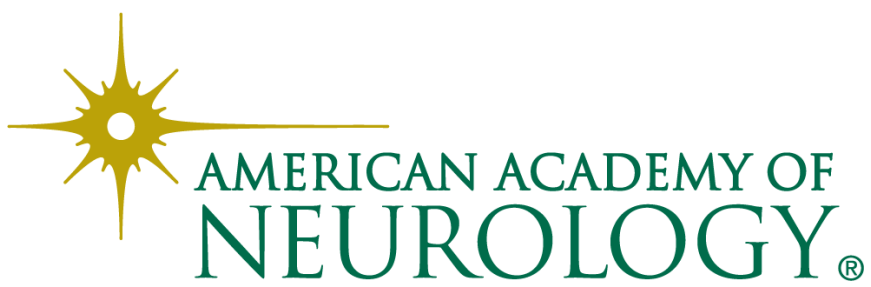

